\title{
Journal of Business Research \\ Business Model Innovation through Digitisation in Social Purpose Organisations: A Comparative Analysis of Tate Modern and Pompidou Centre \\ --Manuscript Draft--
}

\begin{tabular}{|c|c|}
\hline Manuscript Number: & JBR-D-19-00709R3 \\
\hline Keywords: & $\begin{array}{l}\text { business model innovation, hybrid organisations, social purpose organisation, art } \\
\text { museums, digitisation, organisational change }\end{array}$ \\
\hline Corresponding Author: & $\begin{array}{l}\text { Soo Hee Lee } \\
\text { University of Kent } \\
\text { Canterbury, Kent United Kingdom }\end{array}$ \\
\hline First Author: & Nasser Alshawaaf \\
\hline \multirow[t]{2}{*}{ Order of Authors: } & Nasser Alshawaaf \\
\hline & Soo Hee Lee \\
\hline Manuscript Region of Origin: & UNITED KINGDOM \\
\hline
\end{tabular}


Journal of Business Research

Special Issue: Business model innovation in social purpose organizations

\title{
Business Model Innovation through Digitisation in Social Purpose Organisations: A Comparative Analysis of Tate Modern and Pompidou Centre
}

\author{
Nasser Alshawaaf \\ Kent Business School \\ University of Kent \\ Canterbury, CT2 7FS, UK \\ E-mail: sa809@kent.ac.uk \\ Soo Hee Lee* \\ Kent Business School \\ University of Kent \\ Canterbury, CT2 7FS, UK \\ E-mail: s.h.lee@kent.ac.uk \\ Tel: 00441227827895
}

* Corresponding author

**Acknowledgement:

The authors would like to thank the guest editors of the special issue and two anonymous reviewers for their valuable comments and suggestions. Soo Hee Lee acknowledges that his work was supported by the National Research Foundation of Korea (NRF-2017S1A3A2066149). 


\title{
Submitted to the JBR Special Issue on business model innovation in social purpose organizations
}

\section{Business Model Innovation through Digitisation in Social Purpose Organisations: A Comparative Analysis of Tate Modern and the Pompidou Centre}

\begin{abstract}
Combining heterogeneous organisational forms continues to pose unresolved challenges that foster organisational innovation. This study examines the effect of digitisation on the business model of insufficiently funded art museums in the United Kingdom and France influenced by national cultural policies. Based on two representative case studies of Tate Modern and the Pompidou Centre, we found that digitisation is revitalising social purpose organisations by innovating the business model in two ways. First, digitisation enables creative revenue streams that directly feed into the social mission by creating a synergy between trade and social activities. Second, digitisation delivers social value to a larger audience with lower costs by engaging with visitors through virtual experience. Creative utilisation of digitisation provides a mechanism for business model innovation in social purpose organisations with enhanced financial autonomy and greater social value.
\end{abstract}

Keywords: business model innovation, hybrid organisations, social purpose organisation, art museums, digitisation, organisational change 


\section{Introduction}

Digitisation means the transformation of work processes and activities into digital formats in order to drive productivity and growth (Mauro et al., 2015; Brynjolfsson \& McAfee, 2011). Utilising digital technologies often leads to organisational innovation with positive implications that may include improving capabilities and competitive advantages (Svahn et al., 2017; Kyriakou et al., 2017). Previous studies have examined the implications of digital tools that are now the norm such as e-commerce and social media (Bouwman et al., 2018), while digital technologies are evolving rapidly with the continuous development of robots and artificial intelligence (Wirtz et al., 2018; Kaplan \& Haenlein, 2019). The effect of digital technologies on organisations may be explored through examining changes in the business model with increasing evidence that business model innovation (BMI), through novelty in the way an organisation produces and delivers value, enhances organisational performance (Foss \& Saebi, 2017). Value creation processes, value capture processes, and value proposition have been identified as three components of BMI (More et al., 2015; Bouncken \& Fredrich, 2016; Massa \& Tucci, 2013). In particular, value proposition for an innovative service or feature has been related to BMI outcomes (Gummerus, 2013; Dunford et al., 2010; Matzler et al., 2013; Cucculelli \& Bettinelli, 2015). To advance this research, we examine the implications of digitisation on value proposition and consequently BMI outcomes in the context of art museums.

Studies on BMI have generalised findings on all organisational forms neglecting how organisations may differ because of different aims and resources (Morris et al., 2005). Increasingly challenging operational environments are pushing non-profit organisations to adopt commercial practices for survival (Weerawardena et al., 2010). This has led to the emergence of a hybrid organisational form, referred to as social purpose organisations (SPOs) that trade in order to fulfil their social mission (Barraket et al., 2016). In their attempt to 
satisfy conflicting demands from social and commercial missions, SPOs experience internal and external tensions (Battilana \& Lee, 2014; Greenwood et al., 2011). Previous research suggests that combining organisational forms fosters innovation (Haveman \& Rao, 2006), yet the innovative means by which SPOs homogenise conflicting practices is an under-researched avenue. Scholars have called for research into how hybrid organisations manage tensions and innovate to overcome challenges (Battilana \& Lee, 2014; Weerawardena \& Mort, 2012; Frumkin 2002). In this study, we aim to examine the emergence of BMI outcomes in SPOs with a focus on digitisation to understand how it leads to innovation and enables a functional combination of social and commercial missions.

This study examines the effect of digitisation on the business model of insufficiently funded art museums in the United Kingdom and France, as influenced by national cultural policies. We report on the findings from two representative case studies of Tate Modern and the Pompidou Centre (Yin, 2017; Stake, 2005), focusing on digitisation initiatives and their subsequent effects. BMI metrics that include increasing customer value and new value creation are used to account for the emergence of BMI outcomes (Metzler et al., 2013). Following events from the institutional environment that disrupted the operations and capacity of organisations, digital initiatives were proposed and adopted. As SPOs sought to improve financial performance, they developed creative digital revenue streams that directly influenced the social mission and created a synergy between trade and social activities. The social mission is cost-effectively delivered to a greater audience through a virtual experience rather than relying on physical expansion. Creative digital practices increased and diverted income directly into financing social activities, thus leading to enhanced financial autonomy and social performance.

Our study contributes to the literature on BMI and SPOs in three ways. First, digitisation improves organisational performance for SPOs in terms of both social and 
commercial dimensions. Digital projects enhance social outcomes while creating new revenue streams. Second, digitisation leads to BMI by innovating services that interact with customers to build relationships, create new experiences, and engage more closely with audiences. We show that digitisation leads to BMI outcomes through increasing customer value and creating new value, resulting in more visitors and higher self-generated income. Third, we contribute to SPO literature by showing strategies for this type of organisation to combine social and commercial missions in response to a challenging operational environment. Digitisation enables hybrid practices by enhancing social outcomes, developing revenue streams, enhancing donations, and reducing costs.

\section{Social Purpose Organisations and Business Model Innovation}

Social purpose organisations (SPOs) are organisations that are led by a social mission, in their trade, aims and use of profits (Barraket et al., 2016). SPOs trade to generate a substantial self-generated income, the majority of which is reinvested in aspects that will help the organisation to fulfil its social mission known as 'impact investing' (O'Donohoe et al., 2010). SPOs are not categorised as 'for-profit' or 'non-profit' entities, but are instead considered somewhere in between with their financial sustainability derived from commercial activities rather than philanthropy (OECD, 2013). Balancing commercial and social missions is therefore crucial for a successful SPO. A related and common example is social enterprises that aim to achieve both business-related and charitable objectives (Battilana \& Lee, 2014).

The dual identity of SPOs creates internal and external tensions that arise in managing external relationships with different stakeholders and internal resource allocation (Battilana \& Lee, 2014). As the organisation attempts to meet the demands of competing institutional logics, conflicts arise on the individual and organisational levels in relation to roles, activities, legitimacy, governance, and change (Greenwood et al., 2011; Kraatz \& Block, 2008; Diochon, 2010). A critical challenge faced by SPOs is financial such as in the shortfall of 
philanthropic funding sources due to macroeconomic changes (Weerawardena et al., 2010). This puts SPOs under pressure to find new sources of funding, which in turn prompts them to have a greater dependence on trading activities that may disrupt the balance with social activities (Arrow, 2000; Chetkovich \& Frumkin, 2003). Scholars have researched these problems by questioning how SPOs could balance conflicting demands while sustaining their organisations so that they can survive. A stream of research suggests creating a hybrid organisational identity and has developed hybridisation approaches such as hybrid organising (Battilana \& Lee, 2014) or hiring and socialisation (Battilana \& Dorado, 2010). In order to tackle financial problems, SPOs need to develop their financial metrics by enhancing revenues and donations, and reducing costs (McDonald et al., 2015). While scholars used different theoretical perspectives to address the challenges of SPOs, other scholars raised calls to examine the role of innovation in emergent organisational forms such as SPOs (Weerawardena \& Mort, 2012; Frumkin 2002).

Business model innovation (BMI) has emerged as a primary means by which to transform organisations and overcome economic and technological challenges. It is defined as encompassing 'designed, novel, nontrivial changes to the key elements of a firm's business model and/or the architecture linking these elements.' (Foss \& Saebi, 2017, p. 201). It requires a shift from a traditional business model to a new one to innovate value creation and value capture with entrepreneurial activities (Bouncken \& Fredrich, 2016; Massa \& Tucci, 2013). Organisations innovate their business model in order to run struggling operations or develop and grow (Spieth et al., 2014; Zott \& Amit, 2007). Studies of BMI are limited and can be classified into three streams of literature, as follows: 1) BMI as a process; 2) BMI as an outcome; and 3) BMI and organisational implications (Foss \& Saebi, 2017; Dunford et al., 2010; Matzler et al., 2013; Cucculelli \& Bettinelli, 2015; Zott \& Amit, 2007). Innovating organisational processes such as capabilities, leadership, and interaction mechanisms 
eventually leads to innovating the overall model of the organisation (Dunford et al., 2010). For instance, Mair and Marti (2006) have shown that a hospital innovated corporate social responsibility by developing a tiered pricing model based on the patients' ability to pay, thus receiving subsidies from and serving wealthy patients, which then enabled the hospital to serve patients who could not afford medical services. BMI could be an unintended outcome of an organisational change project by which innovation emerges to shape a new business model (Matzler et al., 2013). The emergence of BMI in organisations has positive consequences on financial performance and operational efficiency (Cucculelli \& Bettinelli, 2015; Markides \& Charitou, 2004; Zott \& Amit, 2007).

Research in BMI literature is growing, and there are opportunities to contribute to the existing array of knowledge (Hossain, 2016; Morris et al., 2005). Given the unresolved challenges faced by SPOs, we build on these earlier studies to explore the links between BMI as an outcome and SPO performance to reveal insights for achieving hybrid objectives while sustaining this volatile type of organisations. According to Matzler et al. 'business model innovation results when a company increases customer value and simultaneously creates a new value creation and revenue model that allows the company to capture some of the value created in a new way.' (2013, p. 31). Consequently, there are two dimensions to measure BMI as an outcome: 1) increasing customer value, and 2) new value creation. These will be discussed in the remainder of this section.

\subsection{Increasing Customer Value}

Studies have shown that the outcome of BMI can be measured by observing a significant increase in customer value. This dimension enhances organisational performance by appealing to customers to either pay a higher price for an offering, or make recurring and more frequent purchases. Matzler et al. (2013) have examined how to combine different 
organisational aspects including product, service, sales, marketing, and revenue to develop an ecosystem that creates sustainable and recurring purchases from customers. They analysed BMI for a coffee company and found that introducing capsule coffee machines is an innovation that increased customer value. Rather than intermittent purchases with alluring choices from competitors, the capsule coffee machine locks the customer into the ecosystem of the company by requiring them to make recurring purchases of capsules to use the coffee machine. In contrast, increasing customer value can be achieved through reducing the cost of an offering to the organisation while maintaining the same price and thus gaining a higher margin and value from customers like, for example, the adoption of renewable energy generation by the electric power sector rather than purchasing coal or fossil fuel which decreases the cost of production (Richter, 2013). Therefore, innovations that significantly increase customer value are important for developing BMI outcomes.

\subsection{Creating New Value}

The second dimension for measuring BMI as an outcome is new value creation achieved mainly by making a new offering that provides new value for customers, by solving a problem, saving them money, or allowing more convenient delivery of the offering, that entices them to purchase (Amit \& Zott, 2001). New value creation transforms the business model of organisations through a significant reduction of costs, increase in revenue, or by sustaining a competitive advantage (Matzler et al., 2013). Developing new value can be achieved by either imitating rivals, or through a complex process of exploration and learning whereby innovation is at the centre of this process (Sanchez \& Ricart, 2010). The success of new value creation relies partly on its adoption by customers and the subsequent effect on the organisation (Abdelkafi et al., 2013; Holm et al., 2013). Abdelkafi et al. (2013) have examined business model innovation in the field of electric mobility and have found that the development of electric engine technology transformed the car industry by achieving 
sustainable transportation through electricity that can be generated from renewable sources. Electric mobility is an innovation that represents new value creation that is more appealing to customers as the cost of electric transportation for customers is more efficient economically as well as being more environmentally friendly. In contrast, transforming the business model may have a disruptive impact on industries. For example, Holm et al. (2013) have shown that new value creation for newspapers by building online web presence and mobile apps has eroded the revenue model of organisations in this field. In both cases, BMI as an outcome was observed by new value creation regardless of BMI implications, whether positive or negative. Overall, new value creation that emanates from innovations is critical to the emergence of BMI outcomes.

\section{Digitisation as a Mechanism for Business Model Innovation}

Digitisation is 'the process of converting continuous, analogue information into discrete, digital and machine-readable format, reached broad popularity with the first "mass digitisation" projects' (Mauro et al., 2015, p. 98). From an institutional perspective, digitisation manifests in digital organisational forms, digital infrastructure, and digital activities to drive productivity and growth or generate a competitive advantage (Hinings et al., 2018; Svahn et al., 2017; Kyriakou et al., 2017; Mauro et al., 2015; Brynjolfsson \& McAfee, 2011). For instance, digitisation enables synergies to be created between a firm and its suppliers in order to develop internal capabilities and new products (Svahn et al., 2017). Thus, the combination of human and digital capabilities is significant in terms of organisational competitiveness and survival.

Recent studies have attempted to examine the relationship between digitisation and BMI. Digitisation innovates the business model through the value creation process, value capture process, and value proposition (Mort et al., 2015; Parida et al., 2019). The value 
creation process through digitisation can occur by creating novel offerings, understanding customer needs, and collaborative value creation, new capabilities, and operational processes. The value capture process can occur by improving internal processes for cost efficiency, new revenue streams, and new risk management approaches. Value proposition is an innovative service or feature that attracts customers to use or purchase offerings. Digital applications may be offered through social media and big data that have been found to positively affect the performance of small- and medium-sized enterprises (Bouwman, et al., 2018). This research, however, has examined digital tools that are now the norm in the practices of organisations. We extend this line of research to evolving digital technologies that are having a greater role in increasing customer value and new value creation. Three digital innovations are identified to integrate with the business model, namely are interactive services, services robots, and artificial intelligence.

\subsection{Interactive Services}

Interactive services refers to 'services that have some form of customer-firm interaction in an environment characterised by any level of technology (i.e., a high or low technology environment)' (Bolton \& Saxena-lyer, 2009, p. 92). Customer participation is important for an effective interactive service delivery. For instance, a study in the tourism industry has found that interactive services are positively related to a pleasant touristic experience (Dao \& Yang, 2019). The importance of interactive services in organisations is in increasing the power of consumers, as well as creating synergies between service channels, and during transactions (Berry et al., 2010). Interactive services in shopping experiences are enabling customers to customise products; thus, for example, apparel and footwear manufacturers offer custom product design through their online shops (Kyriakou et al., 2017). Nevertheless, studies have focused on for-profit organisations or specific industries neglecting how this technology can develop emergent organisational forms such as SPOs. 


\subsection{Services Robots}

One stream of literature explored the role of robots in organisations (Wirtz et al., 2018; Ivanov \& Webster, 2019). For internal organisational capabilities, service robots are beneficial for homogenous outputs, and customisation and personalisation of services on a large scale (Wirtz et al., 2018). The extent of functionality of service robots is influenced by their ease of use and usefulness. For instance, service robots should be able to guide the customer through the service process easily as the service employee. An application of service robots was explored in the tourism industry to show that they can be used for housekeeping activities, processing bookings, and payment and documents (Ivanov \& Webster, 2019). Scholars have called to explore more empirical examples of how service robots have been applied in an easy, convenient, and flexible ways that have been adopted by customers (Wirtz et al., 2018).

\subsection{Artificial Intelligence Services}

Artificial intelligence (AI) is defined as 'a system's ability to correctly interpret external data, to learn from such data, and to use those learnings to achieve specific goals and tasks through flexible adaptation' (Kaplan \& Haenlein, 2019, p.15). Research on AI and organisations has covered applications that could be developed to provide offerings to customers (Kaplan \& Haenlein, 2019; Masters, 2019; Huang \& Rust, 2018). AI can be applied by universities to provide virtual teaching assistants, by corporations to increase pace of automation, and by governments to develop automation systems (Kaplan \& Haenlein, 2019). However, AI is not expected to fully replace professions that require cognition such as doctors in medical services but to assist them and create new roles (Masters, 2019). The extent of AI services depends on the mechanical, analytical, intuitive, and empathetic level of the AI (Haung \& Rust, 2018). Scholars argue that AI in services can totally replace human 
services but without evidential applications, as well as the role and effect of AI within the context of SPOs is not clear (Haung \& Rust, 2018).

Although we know from studies that have examined the ways digital technologies have been utilised by organisations (Dao \& Yang, 2019; Ivanov \& Webster, 2019; Kaplan \& Haenlein, 2019; Masters, 2019) that they transform the business model, however, most studies have not differentiated between digitisation of for-profit and non-profit organisational forms. A stream of literature has attempted to connect digitisation more closely with the business model of non-profit organisations (Wang, 2014; Stromberg, 2013). Digitisation is fundamentally changing the practices of non-profit organisations such as museums which are seeking to explore the potential provided by digital technology in order to enhance social value for their audiences and promote cross-cultural understanding, whereby some of them have successfully achieved new ways of interacting and sharing information (Stromberg, 2013; Wang, 2014; Rivero Moreno, 2018). For instance, virtual exhibitions curated by museums for education and entertainment influence the audiences' aesthetic experience and their intention to visit the gallery physically while targeting segments of the public that are interested in new types of interaction (Lee et al., 2019; Carrozzino \& Bergamasco, 2010). When SPOs attempt to balance social and commercial missions, digitisation can be key, as it has the potential to increase customer value and create new values. Through this study of SPOs, we therefore aim to examine the applications of digital technologies that have resulted in BMI outcomes. We seek to understand (1) the digitisation projects by SPOs that are related to interactive services, services robots, and artificial intelligence, and (2) the impact of digital initiatives on the BMI outcomes of increasing customer value and new value creation. 


\section{Research Method}

We conducted a case study analysis of SPOs in the United Kingdom and France to examine digitisation and the resulting BMI outcomes (Yin, 2017; Stake, 1995). The strength of a case study lies in the investigation of a complex situation that consists of several variables in order to gain an in-depth understanding and insights from the phenomenon (Yin, 2017). The study is comparative in order to analyse the similarities and differences of two cross-national cases that share a common strategic focus but with different environmental influences in order to provide more compelling and robust findings (Stake, 2005; Herriott \& Firestone, 1983). External validity is lacking as the study focuses on only two representative cases to provide a 'force of example' as findings are not generalisable (Flyvbjerg, 2006). However, generalisability of case studies can be increased by the strategic selection of the cases (Ragin \& Becker, 1992). Therefore, the cases were selected based on purposeful sampling to discover, understand, and gain insights (Merriam, 1998). The lack of external validity is compensated for with internal validity through data triangulation by collecting data from different internal and external sources to increase the credibility of interpretations, maximise the robustness of the analysis, and the confidence in the conclusions (Bryman, 2015).

The rationale for context selection is to investigate BMI outcomes in SPOs with a particular focus on digitisation. Art museums are institutions that collect, research, display, and preserve art as well as engage with audiences through exhibitions to increase awareness and appreciation of the arts (Smithsonian Institution, 2001). Our choice of cases reflected our desire to capture variation in the objective behind digitisation and explore wider applications of digital technologies in art museums; Tate Modern has embraced commercialisation, and the Pompidou Centre has adopted globalisation. Tate Modern was under pressure in 2009 to cope with the constant shrinking in public funding due to a governmental austerity 
programme. As national museums in the UK are unable to charge an entrance fee (Art Fund, 2009), the remaining options are funding from the private sector and commercial practices to create a self-generated income. The second case is the French museum, the Pompidou Centre, that launched in 2008 a new strategy to become a global player in cultural representation. The centre adopted a globalisation strategy that is different from traditional physical expansion by organising temporary international exhibitions and utilising digitisation to assist in achieving a global presence.

\section{INSERT TABLE 1 ABOUT HERE}

We collected data from secondary sources to provide rich information about the phenomena investigated in order to reveal the bases of decisions on digital projects, and the subsequent outcomes (Stake, 1995). Data were collected from internal documents including annual reports and minutes of meetings, and external sources including newspaper articles, magazine articles, and online articles. A deductive data analysis and theory testing approach has been used to understand whether the theory applies to the context and to strengthen the confidence in findings through 'pattern matching' (Gabriel, 2013; Hyde, 2000; Yin, 2017). Consequently, we used template analysis by integrating the data of cases with a framework (Yin, 2017). The practice of reflexivity, which refers to being self-aware and conscious about one's own a certain perspective, is based on 'careful interpretation' and 'reflection' (Alvesson \& Sköldberg, 2017). We followed this practice by interpreting the meaning of the textual data and the reflection of interpretations on the BMI outcomes of the cases.

Tracking started when both museums launched digitisation projects to achieve their

objectives until a significant change in BMI outcomes was observed, i.e. the period from 2012 to 2018. We identified digitisation initiatives related to objectives determined by (1) how the organisation can adapt to cuts in public funding to increase income and decrease costs, and (2) 
how the organisation can reach and engage with wider audiences to enhance its social mission. We then examined in-depth the identified initiatives focusing on the following questions: 'What is the initiative and underlying purpose, how is it applied, and what is the

outcome?'. Early analysis focused on extracting data about the link between digitisation and change in customer value at Tate Modern and the Pompidou Centre. The analyses included statements and figures of tools that are used to measure customer value and whether they changed significantly after adopting digitisation. Later on, the analysis focused on finding how digitisation resulted in new value creation for the organisation, in particular for SPOs in terms of both trade and social outcomes. Examples of new value creation for art museums include but are not limited to new income streams and new ways to engage with audiences. A story was written by pulling together digital innovations and the effect on BMI outcomes in order to create a thick description (Stake, 1995).

\section{INSERT TABLE 2 ABOUT HERE}

\section{Case Studies}

\subsection{Overview of Tate Modern and the Pompidou Centre}

Tate Modern is a modern art museum that is located in central London and represents a major visitor attraction. The museum was established in 2000 following a decision by Tate Trustees to transform a power station into an international modern and contemporary art museum. The museum contains art from 1500 to the present and welcomes over five million visitors annually (Tate, 2017). Tate Modern has objectives that aim to champion art and its value to society with a particular focus on promoting British, modern, and contemporary arts as well as increasing public understanding and enjoyment of the arts. Collections are displayed to the public in the museum and online on the museum's website. Tate Modern has developed a comprehensive digital strategy that covers audience experiences, practices of the 
museum, and organisational structure and processes. Internally, Tate Modern is adopting digital transformation in the organisation by digitising organisational structure and processes (Stack, 2013). The gallery is aiming to transform itself into a digital organisation by making all departments work with digital activities. Digital transformation requires that new staff are trained and equipped with digital skills as part of their work, organisational processes adopt digital tools for cross-department collaborations, and organisational structure utilises the potential of digital for governance and leadership. Performance indicators have to include digital measures for content, community, revenue, and evaluating organisational change towards digitisation. When analysing the digital initiatives by Tate Modern and the subsequent effects on organisational outcomes, we found that it successfully increased the value of customers and created new value through incremental additions to the business model.

The Pompidou Centre is a contemporary art museum in Paris, France, which was founded in 1977 and displays art from popular figures including Pablo Picasso, Georges Braque, Henri Matisse, among others (Centre Pompidou, 2018). The main gallery in Paris is a high-tech architecture building and one of the largest art museums in the world with over 100,000 works. There have been more than 180 million visitors to the museum since its opening in 1977, and as of 2017 it welcomes over three million visitors annually. Around twenty special exhibitions are organised each year with the aim to explore interactions between visual arts (CGI, 2014). In addition to exhibitions, the Pompidou Centre organises conferences and debates on society and encourages the public to attend these events as part of a social mission for education and learning (Azimi \& Régnier, 2015). The Pompidou Centre is one of the first art museums in France to conduct international exhibitions by opening galleries in Malaga and Shanghai among other places. According to the museum, it is part of an updated strategy to be a global player and strengthen links with emerging markets such as 
China and Latin America (Centre Pompidou, 2007). The international strategy mainly involves temporarily galleries being set up for months or years (e.g. Malaga exhibition for five years). The centre is adapting a nationwide policy of cultural decentralisation. Cultural decentralisation implies the deconcentrating of cultural presence to go beyond local presence. Pompidou's strategy that is mentioned in annual reports widely confirms this orientation to work towards national and international presence for its collection.

"To work forcefully towards cultural decentralization, the Center Pompidou must go to the public, share more widely the riches of the collection, to promote the exchange." (Centre Pompidou, 2008, p. 33)

\subsection{Building Relationships}

Tate Modern utilised digitisation to increase customer value through many initiatives. One such example is the Tate Time Machine that interacts with the audience by showing past events of how art has been shaped by history, asks audiences to predict the future of art, and takes their contact data to send them an email in a year's time. It is a learning machine and a form of marketing involving collecting users' data to communicate and promote the museum. Rather than a traditional unattractive opt-in approach, interactive services combined opt-in with an appealing learning experience. This creative service has had an effect on the social performance and hence BMI outcome. First, the Tate Time Machine is a tool that increases customer value by taking visitors' contact data and communicating with them based on their request as a form of interaction with customers. In this way, the consent of customers to optin is gained in a creative way that keeps them engaged with the gallery and future events and exhibitions. Second, the Time Machine provides new value through an interactive service that transforms the way audiences engage with art and its story. This digital project additionally 
provides a competitive advantage as it is a creative service to engage with audiences and makes it more attractive to visit the gallery and enjoy this interactive experience.

The main outcome for Tate Modern is enhancing audience engagement through innovative means. The original objective behind the interactive service was to generate buzz and make people talk about the new Tate Modern extension; however, it provided unintended insights by redefining how people see art. As such, it marks a digital transformation enabling the experiencing of art from traditional visits to be more engaging and entertaining. Many audiences perceived the machine as a creative idea that transforms the way they engage with art.

"Through the Time Machine, audiences get a taste of what the new Tate Modern experience will be like - seeing some of their favourite works in a new light, while discovering artists that they may never have heard of before." - Organisational Actor (Blue State Digital, 2018, para. 7)

"I've seen them countless times and I will continue to see them until they stop playing."

- Consumer

In general, the Tate Time Machine is an interactive service that has achieved multiple objectives to collect audiences' data, enhance audience retention, and improve art experiences. Although the Tate Time Machine was not a large-scale project, the successful outcome shows that interactive services enhance social mission by providing an innovative and appealing experience while feeding into business metrics by developing marketing performance through communicating with audiences leading to higher retention.

\subsection{Creating New Aesthetic Experience}


Another creative digital project initiated by Tate Modern is the After Dark that enables audiences to control robots to roam inside the gallery (Trendall, 2017). Robots are active only at night during closing hours and through them users can discover and see art. The robots include artificial intelligence that shows information about art when the visitor sees them. Tate Modern is the first gallery to deploy robots to see and learn about art in the actual gallery rather than scanned arts thus marking a new way to experience art. The After Dark project creates a new aesthetic experience as audiences can interact with art inside the gallery from their homes. It enhances learning by attracting audiences to engage with art at night in a way that is similar to other sedentary activities at home. The creativity of the project lies in utilising closing hours at night to keep the gallery open by using robots. In addition to convenience, it provides new value as audiences are able to visit the gallery virtually. Visiting through robots and roaming inside the gallery is a more realistic experience than viewing art on websites and represents the most advanced innovation to experience the actual visit virtually.

"You forget about the robot in your hands, and it just becomes an extension of your mind - that's how technology ought to be." - Astronaut (Kennedy, 2014, para. 8)

The roaming robots affect the social mission of Tate Modern by mainly increasing the reach of art and redefining arts engagement. As the gallery is inactive during night hours and the showroom is idle, developing the new digital approach to experiencing art serves audiences who cannot attend opening hours and extends the reach to wider audiences as over 40,000 people have used the new service (Tate, 2015). Additionally, some audiences may prefer a robotic experience rather than visiting the gallery thus providing vacant spaces for other visitors to attend during opening hours leading overall to more capacity and visitors. The other fundamental effect of the robotics experience is to mark a new way to interact with 
art. The success of this innovation may encourage other organisations in the field to imitate the project leading to diffusion and to it becoming a norm when experiencing art.

"Over 40,000 people worldwide tuned in to watch the live stream. Colonel Chris Hadfield, former Commander of the International Space Station, was the first person to drive one of the robots, which he did from his home in Toronto, tweeting about it to his one million followers." (Tate, 2015, p. 34)

"Depending on your computer you can't always control them but you can still watch the 4 robots exploring. You fill out a form and if you fit the brief you go in a queue to control them ... I had a look the last two nights (as they appear to be in different parts of the museum on different nights) and it was pretty cool." - Consumer

Robotics is not the only digital initiative by Tate Modern to provide a new experience. The gallery embraced virtual reality with an exhibition that allowed visitors to experience a three-dimensional model of an artist's studio based in Paris (Coates, 2019). The exhibition successfully conveyed a realistic and recreational experience that represent an attractive new way to interact with art.

"It's a way of conveying feeling, helping people feel a connection with an artist. It's a different way of absorbing that information, and it makes the artist a living person." Organisational Actor (Coates, 2019, para. 18)

Tate Modern developed the After Dark project that enables audiences to roam inside the gallery at night from their homes in partnership with a robotics supplier. This project, alongside the virtual reality exhibitions, resulted in the emergence of BMI outcomes by creating new value for audiences to use and experience art. Through such innovations, more 
audiences interact with the gallery and art digitally which delivers the social mission at lower costs.

\subsection{Audience Engagement}

Engaging with audiences is crucial for art museums to deliver their social mission as audiences have to see art and learn about the story behind each piece. The Pompidou Centre in Paris has developed a digital strategy with the objective of audience engagement on a global scale. The 'Virtual Pompidou Centre', an internet-based broadcasting platform of cultural contents and engaging with audiences, represents a major digital project that was launched in 2012 in collaboration with the private sector (Beaumont, 2013; CGI, 2014). The virtual experience is available for free and provides users with around 100,000 digital resources including images, text, video, and sound of art works, photographs, exhibition posters, among others. The interactive experience is based on three mechanics: first, a categorisation of the content by type and genre; second, a semantic structuring of resources implemented by interconnection between the centre's different practices of collections, programs, activities, and research; third, a customised semantic path where the user is able to navigate through contents conveniently by searching or browsing resources associated with an artist such as works or events.

The virtual centre contributes to the emergence of BMI outcomes. The main outcome derived from the virtual centre is new and higher audience engagement. By engaging with audiences virtually to provide an alternative to the gallery visit, audiences are likely to visit the gallery virtually more frequently thus leading to increases in customer value. The virtual centre provides access to art globally whereby audiences everywhere with a device and internet access are able to visit the gallery. This creates new value for customers that adds to the physical visit. The gallery moves closer to achieving the global objective by using 
digitisation to provide new ways for audiences abroad to visit the gallery virtually. This expands cultural presence to wider audiences from different demographics. Importantly, the gallery achieves the main metric to measure the success of the social mission by showing art and delivers knowledge to larger audiences to have a higher visitors level that is fundamental to maintaining legitimacy and claiming external funding (see Figure 1).

"In my opinion, what is disappearing is a world where there are producers on one side and consumers on the other. Other models are beginning to develop with the digital revolution. On the Internet, there are neither producers nor consumers, but contributors. We are entering into the new logic of the contributive economy, which relies on personal and collective investments and creates another form of value." Organisational Actor (Benhamou, 2009, para. 4)

"This is like shocking to people of an art background, we learn about this place in college in some cultural arts classes and have to write papers about some of the exhibitions in both these places, can u imagine the cultural impact they have for them to be offered this?" - Consumer

Pompidou's virtual centre is an interactive experience that aims to reach wider audiences to engage with art as an alternative to visiting the centre. The digital project leads to the emergence of BMI outcomes and marks an innovative type of audience engagement that other museums in the field can imitate to have higher impact from art and increased visitors.

\section{INSERT FIGURE 1 ABOUT HERE}

\subsection{Diversifying Self-Generated Income}


Unlike other attractions in London, national museums including Tate Modern are free of charge to visitors (Art Fund, 2009). However, Tate Modern charges for other services such as special exhibitions, the gift shop, and a membership scheme. The museum is seeking sponsorship and partnerships to increase income and cover operational costs. Beside commercial income streams, Tate Modern has a charitable foundation that aims to collect donations and grants in order to fund exhibitions, learning activities, and research. Digitisation is utilised by Tate Modern to create revenue streams through different methods. The gallery launched an online membership dashboard to manage and pay for the membership and stay informed about upcoming events. The membership scheme provides a variety of benefits such as members' hours to enjoy special exhibitions, members' rooms, discounts in the Tate shop, and other benefits. Members can attend unlimited exhibitions and events without additional payments and get priority entry to the museum without having to queue. Moreover, they receive discounts at the museum's shops, cafes, and restaurants. Although members do not pay for exhibitions, which reduces the income per visitor, having them as members ensures loyal customers and a sustained income (see Figure 2). Members are a vital financial source for Tate Modern and the largest source of income after the government grants (Tate, 2018). The impact of the online membership on the business model of Tate Modern is having a predictable income that creates some form of sustainability rather than the volatile public funding (Brown, 2013). Thus, Tate Modern shifted the revenue model significantly from being externally dependent to internally self-generated. Nevertheless, the gallery has not become a traditional business but innovated the business model through the example of the online membership that generates consistent income to finance the gallery while maintaining the social mission of artistic activities and free admission.

INSERT FIGURE 2 ABOUT HERE 
The virtual Pompidou Centre has provided new opportunities for self-generated income through sponsorships as brands gain a greater global exposure to customers than from sponsoring the physical gallery. By providing greater reach to the sponsor, the centre is able to request a higher price from the higher exposure. The virtual centre has successfully attracted sponsorships that has financed the development of the virtual centre and provided a new revenue stream. Additionally, the virtual centre provides new value for artists as their works are exposed to greater audiences. Thus, the Pompidou Centre created new value through the virtual centre by primarily expanding the exposure to wider audiences which corresponds to the centre's globalisation vision, and aim to achieve higher engagement with art, and higher return from sponsors as well as benefiting the audiences by having low-cost and convenient access to art.

The digital projects enabled diversification of self-generated income by increasing customer value and creating new values that led to customer purchases. E-commerce by Tate Modern provided new value for customers to buy souvenirs, art prints, and other items through the online shop thus developing revenues. The virtual centre by Pompidou increased customer value by providing opportunities for sponsorship that are displayed for visitors to view. While the case studies show separate digital projects, the combined effect of online sponsorship and the online shop are important to develop the financial aspect of social purpose organisations and decrease the dependence on grants and donations while maintaining the focus on the social mission.

"I really believe in the mutual enrichment between the Centre, its collections and multiple existing venues. I don't believe in a Centre with multiple branches. Overseas, things are different: it's a question of the brand's presence, of France's renown, of diffusion of the Centre Pompidou model. This is a way for us to get to know the foreign artistic scene and to enrich our collections. Given the current financial situation, this 
type of contribution is very important. One-third of our own resources comes from sponsorship and this type of contract for using our brand." - Organisational Actor (Art Media Agency, 2018, para. 6)

“'Invisible' and 'normalized', this is what they hope digital would become. Digital is a driver for collaboration and a merger of functions that were previously conceived as separate, a transformation and a process the institution has to go through to have an impact on the audiences." - Consumer

Digitisation has enabled both Tate Modern and the Pompidou Centre to enhance their financial aspects to diversify self-generated income and depend less on grants-in-aid. Thus, digitisation can be utilised for dual objectives to strengthen the social mission and develop revenue streams conforming to the hybrid structure of social purpose organisations.

\section{Discussion}

We have examined art museums in the UK and France to shed light on how digitisation has innovated business models of SPOs to serve competing missions homogenously. Our study is interdisciplinary combining SPO, BMI, digitisation, and a comparative perspective to make mutual theoretical development in different disciplines (Gustafsson et al., 2016). The study demonstrates how digital technologies of interactive services, services robots, and artificial intelligence lead to BMI outcomes. We advance our understanding in three ways: (1) we show that digitisation leads to BMI outcomes and improves organisational performance; (2) we highlight that digitisation serves and harmonises competing missions; and (3) we explain the ways in which digitisation creates a synergy between social and commercial objectives.

\subsection{Improving Organisational Performance}


First, digitisation leads to BMI through innovating and digitising services to interact with customers by building relationships, creating new experiences, and engaging with audiences. The findings illustrate extensions to the business model through new outcomes without a total replacement of conventional services in the social domain and the physical gallery still exists. This study confirms the findings of previous studies that digitisation leads to positive organisational implications (Svahn et al., 2017; Kyriakou et al., 2017; Foss \& Saebi, 2017; Dunford et al., 2010; Markides \& Charitou, 2004). Digitisation itself is not the innovation but the creative ways of utilising digital technologies makes it an innovative component in the business model. Our analysis shows that digitisation affected organisational performance in terms of both social and financial outcomes. Socially, digital transformation resulted in new and enhanced ways of achieving cultural reach to deliver the social mission to greater audiences. Financially, digitisation enabled new revenue streams by acting as a sales channel and provided more convenient access to paid services. For example, virtual visitors to the Pompidou Centre surpassed visitors to the physical gallery while generating advertising revenue from sponsorship of the online gallery. Thus, creative utilisation of digitisation leads to enhanced hybridity of the business model, but importantly the effect is significant resulting in BMI outcomes.

\section{INSERT FIGURE 3 ABOUT HERE}

\subsection{Serving Competing Objectives}

Second, the findings show that innovation varied according to the influences from the institutional environment and the scope of the organisational mission. We contribute to the SPO literature by showing that digitisation allowed this hybrid type of organisations to adapt to a challenging operational environment. While Battilana and Lee (2014) have proposed organisational processes to combine social and commercial objectives, we add to this by 
illustrating digitisation as a mechanism that enables this combination through different creative configurations. Digitisation offers the opportunity to achieve hybridity by combining social and commercial models or pursuing them separately.

The cases of Tate Modern and the Pompidou Centre help to show a clearer pattern. Both are SPOs with social objectives which have innovated their business model through digitisation in order to respond to threats and survive. However, the innovation between the two organisations varies although the transformation is through digital means and the primary objective is to improve social outcomes. Tate Modern utilised digitisation to increase the efficiency of interaction with audiences and improve organisational performance. It successfully achieved new revenue streams and lower operational costs to balance the budget. Nevertheless, the initial focus of Tate Modern on digital was to enhance social impact by reaching audiences and provide interesting ways to engage with art but the emerging funding dilemma prompted the museum to employ digitisation to confront the threat of shrinking public funding and achieve financial autonomy. Thus, Tate Modern's digital projects achieved hybrid objectives relating to social impact, higher income, and lower costs. The noticeable innovation is the creativity of digital projects that successfully served the three objectives. Increasing customer value through frequent engagement with art and new value creation through revenue streams advanced both the social and commercial components of the business model.

The Pompidou Centre utilised digitisation in a different way because although the museum carries a social mission, it slightly differs in scope compared to Tate Modern. The centre is not prioritising funding like Tate Modern but aims to enhance cultural reach through a global presence. Digital transformation was initiated to reach more audiences worldwide and provide them with a virtual reality experience to engage with French art without the need to travel and visit the physical gallery. The virtual centre has a fundamental impact on the 
business model of the Pompidou Centre by providing virtual access to contents to wider audiences. Rather than spending capital on building galleries with all the overhead costs, the virtual centre is one project cost that allowed global access to the gallery for any individual with a device and internet access. Thus, from the financial aspect the virtual centre reduced costs significantly for both the centre and the consumer while attracting sponsorship income. From the cultural aspect, audiences are engaging with art from the comfort of their homes. Thus, by increasing customer value through greater reach and new value creation through online income streams, BMI emerged by advancing both the social and commercial outcomes.

\subsection{Synergy between Social and Commercial Objectives}

Third, the case studies reveal several ways by which digitisation enabled art museums to create a synergy and a balance between the social mission and trading activities. The study of McDonald et al. (2015) provided a typology for SPOs to incorporate the commercial model by creating revenue streams, enhancing donations, and reducing costs. We suggest that digital technologies of interactive services, services robots, and artificial intelligence are a springboard by which to achieve these strategies. For example, the After Dark robot roaming inside the gallery increased visitor levels and social impact while feeding into the financial aspect as the gallery is kept open during the night with lower costs than the average operating costs during opening hours. On the other hand, digitisation with a financial aim influenced the social aspect whereby, for example, the online membership enhanced revenues from membership and fed into the social activities as members are more likely to attend free or discounted exhibitions. Digital audience engagement such as the virtual experience of the Pompidou Centre has a fundamental impact on the business model. It provides virtual access to contents for people all over the world with a twofold effect: first it allows greater cultural reach globally at lower cost, and second, it increases income from sponsorship as brands gain 
greater exposure to customers on a global scale. Thus, digitisation has resulted in higher income and lower costs while feeding into the social mission.

While the literature suggests that the duality of missions is a source of organisational tensions (Battilana \& Lee, 2014; Greenwood et al., 2011), we have shown that digitisation can enable a creative harmony between competing activities to achieve hybridity. Nevertheless, digitisation has the potential to create unexpected tensions in other organisational aspects. Interactive services that enable audiences to create, reuse, and circulate art may undermine the role of artists and curators in terms of the social impact as power is shifting to audiences. Furthermore, organisations have limited resources and allocating them to invest in digital projects may lead to conflicts about whether the impact of investing should be prioritised for social or commercial outcome (O’Donohoe et al., 2010). While the cases show a successful synergy between conflicting objectives, however, the combination is the result of changing priorities as the analysis shows where digital has been utilised for one organisational objective first and then developed to combine a second objective. We believe that this synergy is important to reduce or eliminate potential tensions, as drawing the organisation away from the core social mission triggers conflicts between stakeholders while commercial activities are a necessity in the face of insufficient public funding.

\section{Conclusion}

Non-profit organisations are under increasing pressure to secure self-sufficient funding sources, leading to the adoption of hybrid organisational forms termed SPOs (Weerawardena et al., 2010). SPOs are vulnerable to internal and external tensions emanating from the duality of missions (Battilana \& Lee, 2014). Our study suggests that understanding how SPOs address tensions arising from hybridity requires a focus on the role and effect of digitisation in their pursuit of social and commercial missions. By examining this interface, 
our study identifies a synergy created by digitisation between conflicting objectives. We observe that the dynamics of digitisation enable creative utilisation by SPOs to innovate the business model and achieve hybrid outcomes on a large scale. The difference in the emerging BMI depends on the circumstances and goals of SPOs as innovations are aimed at organisational survival and serve the particular scope of the social mission. Another issue is maintaining legitimacy which requires meeting the expectations of multiple stakeholders including the community, artists, and staff. This partially explains the difference in digital adoption as the demands imposed by the institutional environment and stakeholders contribute to the shape of BMI. The optimal digitisation for SPOs is to consider both social and commercial dimensions to achieve maximum return on investment and maintain legitimacy that eventually results in BMI outcomes.

SPOs could learn from the cases of Tate Modern and the Pompidou Centre that have successfully coped with shrinking funding and enhanced social impact as they utilised digitisation creatively and effectively. We suggest that digital initiatives in SPOs should carry a hybrid objective to achieve social and commercial outcomes in order to have better chances of survival and meet institutional challenges. In addition, SPOs should aim to have a creative synergy between social and trading activities through digital projects to develop a sustainable ecosystem (Weerawardena et al., 2010). This implies that SPOs should consider every digital project from the social and commercial dimensions that conform to 'impact investing', as digital could be viewed as a business investment with the intention to generate social impact (O’Donohoe et al., 2010).

Our research has a number of limitations that can be addressed through future research. Diverse sources of secondary data used in this research (e.g. Tate, 2013, 2014, 2015, 2016, 2017; Pompidou Centre, 2017; Art Fund, 2009; Stack, 2013) suggest that Tate Modern and the Pompidou Centre successfully innovated the business model and achieved financial 
autonomy alongside the social mission, following a digitisation approach to organisational services (Dunford et al., 2010). We compensated for the limitations in secondary sources through data triangulation by using multiple internal and external sources of data to increase the credibility of interpretations and the confidence in conclusions (Bryman, 2015). This limitation could be addressed in future research by conducting interviews within SPOs to explore the effect of digitisation on internal organisational structure and staff interactions. Our findings illustrate that digitisation extended the business model of SPOs through BMI outcomes; future research could examine cases where the whole business model is replaced to transform art museums totally into digital galleries. Although digitisation was examined as a primary mechanism for BMI outcomes, other mechanisms could be identified and examined by future research to demonstrate innovations in SPOs that are affecting their internal processes, performance, and the overall business model. While this study has linked digitisation directly to organisational outcomes (Cucculelli \& Bettinelli, 2015; Markides \& Charitou, 2004), future studies could examine moderators that may influence the extent of digitisation effects. This study focused on digitisation but how it interacts with other mechanisms and processes would be an interesting area of study to gain more understanding of how SPOs combine social and commercial objectives in a hybrid arrangement. We examined specific digital technologies and particular innovations, yet others could be explored to examine potentially different effects on business models. Furthermore, the findings of this study based on art museums may not be generalisable to other fields of SPOs. Future research could explore digitisation in different contexts other than art museums to examine different kinds of innovations that have affected the business model depending on the unique circumstances of the field. 


\section{References}

Abdelkafi, N., Makhotin, S., \& Posselt, T. (2013). Business model innovations for electric mobility — what can be learned from existing business model patterns? International Journal of Innovation Management, 17(01), 1-41. doi:https://doi.org/10.1142/S1363919613400033

Alvesson, M., \& Sköldberg, K. (2017). Reflexive methodology: New vistas for qualitative research (3rd ed.). London: SAGE Publications.

Amit, R., \& Zott, C. (2001). Value creation in e- business. Strategic Management Journal, 22(6- 7), 493-520. doi:https://doi.org/10.1002/smj.187

Art Fund. (2009). Free admission boosts sense of public ownership of national museums. Retrieved from https://www.artfund.org/news/2009/06/29/free-admission-boosts-senseof-public-ownership-of-national-museums

Art Media Agency. (2018). Centre Pompidou Malaga three years down the track. Retrieved from https://en.artmediaagency.com/121165/centre-pompidou-malaga-three-years-down$\underline{\text { the-track/ }}$

Avery, J. (2014, The Tate's digital transformation.

Azimi, R., \& Régnier, P. (2015). It takes a Pompidou Center that engages in the great debates of society. Retrieved from https://www.lequotidiendelart.com/articles/7898--il-faut-uncentre-pompidou-qui-s-engage-dans-les-grands-debats-de-societe.html

Barraket, J., Mason, C., \& Blain, B. (2016). Finding Australia's social enterprise sector 2016. Social Traders and Center for Social Impact. Retrieved from http://www.csi.edu.au/media/uploads/FASES_2016_full_report_final.pdf

Battilana, J., \& Lee, M. (2014). Advancing research on hybrid organizing-Insights from the study of social enterprises. Academy of Management Annals, 8(1), 397-441. doi:https://doi.org/10.5465/19416520.2014.893615

Beaumont, E. (2013). The virtual Centre Pompidou, a new strategy to acquire and publish digital content thanks to a strong sponsorship. Retrieved from http://www.tafterjournal.it/2013/02/22/the-virtual-centre-pompidou-a-new-strategyto-acquire-and-publish-digital-content-thanks-to-a-strong-sponsorship/ 
Benhamou, E. (2009). Bernard Stiegler: "Consumerism has reached its limits". Retrieved from https://www.latribune.fr/actualites/economie/france/20090723trib000402565/bernar d-stiegler-le-consumerisme-a-atteint-ses-limites.html

Berry, L. L., Bolton, R. N., Bridges, C. H., Meyer, J., Parasuraman, A., \& Seiders, K. (2010). Opportunities for innovation in the delivery of interactive retail services. Journal of Interactive Marketing, 24(2), 155-167. doi:https://doi.org/10.1016/j.intmar.2010.02.001

Blue State Digital. (2018). How do you get the world talking about the new Tate modern? Retrieved from https://www.bluestatedigital.com/our-work/tate-modern/

Bolton, R., \& Saxena-Iyer, S. (2009). Interactive services: A framework, synthesis and research directions. Journal of Interactive Marketing, 23(1), 91-104.

doi:https://doi.org/10.1016/j.intmar.2008.11.002

Bouncken, R. B., \& Fredrich, V. (2016). Business model innovation in alliances: Successful configurations. Journal of Business Research, 69(9), 3584-3590. doi:https://doi.org/10.1016/j.jbusres.2016.01.004

Bouwman, H., Nikou, S., Molina-Castillo, F. J., \& de Reuver, M. (2018). The impact of digitalization on business models. Digital Policy, Regulation and Governance, 20(2), 105-124. doi:http://dx.doi.org/10.1108/DPRG-07-2017-0039

Brown, M. (2013). Tate Modern installs interactive screens to let visitors be artists - or critics. Retrieved from https://www.theguardian.com/artanddesign/2013/sep/19/tate-moderninteractive-screens-visitors

Bryman, A. (2015). Social research methods (5th ed.). Oxford, UK: Oxford University Press.

Brynjolfsson, E., \& McAfee, A. (2011). Race against the machine: How the digital revolution is accelerating innovation, driving productivity, and irreversibly transforming employment and the economy. Lexington, Massachusetts: Digital Frontier Press.

Carrozzino, M., \& Bergamasco, M. (2010). Beyond virtual museums: Experiencing immersive virtual reality in real museums. Journal of Cultural Heritage, 11(4), 452-458. doi:https://doi.org/10.1016/j.culher.2010.04.001

Centre Pompidou. (2007). The Centre Pompidou strategic directions. Paris: Centre Pompidou.

Centre Pompidou. (2008). Activity report. Paris: Centre Pompidou. 
Centre Pompidou. (2017). Activity report. Paris: Centre Pompidou.

CGI. (2014). The virtual Pompidou Centre, France: Increasing access to the centre's vast resources. Montreal, Quebec, Canada: CGI Group Inc.

Chetkovich, C., \& Frumkin, P. (2003). Balancing margin and mission: Nonprofit competition in charitable versus fee-based programs. Administration \& Society, 35(5), 564-596. doi:https://doi.org/10.1177/0095399703256162

Coates, C. (2019). Virtual reality is a big trend in museums, but what are the best examples of museums using VR? Retrieved from https://www.museumnext.com/article/howmuseums-are-using-virtual-reality/

Cucculelli, M., \& Bettinelli, C. (2015). Business models, intangibles and firm performance: Evidence on corporate entrepreneurship from Italian manufacturing SMEs. Small Business Economics, 45(2), 329-350. doi:https://doi.org/10.1007/s11187-015-9631-7

Dao, T. T., \& Yang, C. (2019). Impact of interactive service on international customers' behavior intentions regarding local tourism services in Vietnam: The mediating effects of pleasant arousal and memory. International Journal of Business \& Information, 14(1), 145-167. doi:https://10.0.26.46/ijbi.201903 14(1).0006

Dawood, S. (2016). Tate time machine, by blue state digital and Tate Modern. Retrieved from https://www.designweek.co.uk/inspiration/tate-time-machine-blue-state-digital-tate$\underline{\text { modern/ }}$

Dees, J. G. (2003). New definitions of social entrepreneurship: Free eye exams and wheelchair drivers. Knowledge Wharton Newsletter, 12(10), 3-16.

Diochon, M. C. (2010). Governance, entrepreneurship and effectiveness: Exploring the link. Social Enterprise Journal, 6(2), 93-109. doi:https://doi.org/10.1108/17508611011069248

Dunford, R., Palmer, I., \& Benveniste, J. (2010). Business model replication for early and rapid internationalisation: The ING direct experience. Long Range Planning, 43(5-6), 655-674. doi:https://doi.org/10.1016/j.1rp.2010.06.004

Flyvbjerg, B. (2006). Five misunderstandings about case-study research. Qualitative Inquiry, 12(2), 219-245. doi:https://doi.org/10.1177\%2F1077800405284363 
Foss, N. J., \& Saebi, T. (2017). Fifteen years of research on business model innovation: How far have we come, and where should we go? Journal of Management, 43(1), 200-227. doi:https://doi.org/10.1177/0149206316675927

Framestore. (2018). 'Explore' spaces. Retrieved from https://www.framestore.com/work/explore-spaces

Gabriel, D. (2013). Inductive and deductive approaches to research. Retrieved from http://deborahgabriel.com/2013/03/17/inductive-and-deductive-approaches-toresearch/

Gasparotti, V. (2014). The Tate digital strategy: A change that starts from within. Retrieved from http://www.svegliamuseo.com/en/la-digital-strategy-della-tate-il-cambiamento-cheparte-dallinterno/

Greenwood, R., Raynard, M., Kodeih, F., Micelotta, E. R., \& Lounsbury, M. (2011). Institutional complexity and organizational responses. Academy of Management Annals, 5(1), 317-371. doi:https://doi.org/10.5465/19416520.2011.590299

Gummerus, J. (2013). Value creation processes and value outcomes in marketing theory: Strangers or siblings? Marketing Theory, 13(1), 19-46. doi:https://doi.org/10.1177\%2F1470593112467267

Gustafsson, A., Högström, C., Radnor, Z., Friman, M., Heinonen, K., Jaakkola, E., \& Mele, C. (2016). Developing service research-paving the way to transdisciplinary research. Journal of Service Management, 27(1), 9-20. doi:https://doi.org/10.1108/JOSM-03-2015-0098

Herriott, R. E., \& Firestone, W. A. (1983). Multisite qualitative policy research: Optimizing description and generalizability. Educational Researcher, 12(2), 14-19. doi:https://doi.org/10.3102/0013189X012002014

Hinings, B., Gegenhuber, T., \& Greenwood, R. (2018). Digital innovation and transformation: An institutional perspective. Information and Organization, 28(1), 52-61. doi:https://doi.org/10.1016/j.infoandorg.2018.02.004

Holm, A. B., Günzel, F., \& Ulhøi, J. P. (2013). Openness in innovation and business models: Lessons from the newspaper industry. International Journal of Technology Management, 61(3/4), 324-348. doi: $\underline{\text { ttps://ssrn.com/abstract=2243493 }}$ 
Hossain, M. (2017). Business model innovation: Past research, current debates, and future directions. Journal of Strategy and Management, 10(3), 342-359. doi:https://doi.org/10.1108/JSMA-01-2016-0002

Huang, M., \& Rust, R. T. (2018). Artificial intelligence in service. Journal of Service Research, 21(2), 155-172. doi:https://doi.org/10.1177\%2F1094670517752459

Hyde, K. F. (2000). Recognising deductive processes in qualitative research. Qualitative Market Research: An International Journal, 3(2), 82-90. doi:https://doi.org/10.1108/13522750010322089

Ivanov, S., \& Webster, C. (2019). Perceived appropriateness and intention to use service robots in tourism. Paper presented at the Information and Communication Technologies in Tourism 2019, 237-248.

Kaplan, A., \& Haenlein, M. (2019). Siri, siri, in my hand: Who's the fairest in the land? on the interpretations, illustrations, and implications of artificial intelligence. Business Horizons, 62(1), 15-25. doi:https://doi.org/10.1016/j.bushor.2018.08.004

Kennedy, M. (2014). Follow that robot: The hi-tech tour guides taking over Tate Britain at night. Retrieved from https://www.theguardian.com/artanddesign/2014/aug/12/robot-arttour-tate-britain-at-night

Kraatz, M. S., \& Block, E. S. (2008). Organizational implications of institutional pluralism. In R. Greenwood, C. Oliver, R. Suddaby \& K. Sahlin (Eds.), The SAGE handbook of organizational institutionalism (pp. 243-275). London: SAGE Publications. doi:http://dx.doi.org/10.4135/9781849200387.n10

Kyriakou, H., Nickerson, J. V., \& Sabnis, G. (2017). Knowledge reuse for customization: Metamodels in an open design community for 3D printing. MIS Quarterly, 41(1), 315332. doi:https://doi.org/10.25300/MISQ/2017/41.1.17

Lee, H., Jung, T. H., tom Dieck, M. C., \& Chung, N. (2019). Experiencing immersive virtual reality in museums. Information \& Management, 103229. doi:https://doi.org/10.1016/j.im.2019.103229

Mair, J., \& Marti, I. (2006). Social entrepreneurship research: A source of explanation, prediction, and delight. Journal of World Business, 41(1), 36-44. doi:https://doi.org/10.1016/j.jwb.2005.09.002 
Markides, C., \& Charitou, C. D. (2004). Competing with dual business models: A contingency approach. Academy of Management Perspectives, 18(3), 22-36. doi:https://doi.org/10.5465/AME.2004.14776164

Massa, L., \& Tucci, C. L. (2013). Business model innovation. In M. Dodgson, D. Gann \& N. Phillips (Eds.), The Oxford handbook of innovation management (pp. 420-441). Oxford, UK: Oxford University Press.

doi:https://doi.org/10.1093/oxfordhb/9780199694945.013.002

Masters, K. (2019). Artificial intelligence in medical education. Medical Teacher, 41(9), 1-5. doi:https://doi.org/10.1080/0142159X.2019.1595557

Matzler, K., Bailom, F., Friedrich von den Eichen, Stephan, \& Kohler, T. (2013). Business model innovation: Coffee triumphs for Nespresso. Journal of Business Strategy, 34(2), 30-37. doi:https://doi.org/10.1108/02756661311310431

McDonald, R. E., Weerawardena, J., Madhavaram, S., \& Sullivan Mort, G. (2015). From "virtuous" to "pragmatic" pursuit of social mission: A sustainability-based typology of nonprofit organizations and corresponding strategies. Management Research Review, 38(9), 970-991. doi:https://doi.org/10.1108/MRR-11-2013-0262

Merriam, S. B. (1998). Qualitative research and case study applications in education. (2nd ed.). San Francisco, California: Jossey-Bass.

Morris, M., Schindehutte, M., \& Allen, J. (2005). The entrepreneur's business model: Toward a unified perspective. Journal of Business Research, 58(6), 726-735. doi:https://doi.org/10.1016/j.jbusres.2003.11.001

Mort, G. S., Weerawardena, J., Sargeant, A., \& Bennett, R. (2015). Social entrepreneurship and value creation in not-for-profit organizations. In C. Colin (Ed.), Marketing in transition: Scarcity, globalism, \& sustainability (pp. 372-376). Cham, Switzerland: Springer.

O’Donohoe, N., Leijonhufvud, C., Saltuk, Y., Bugg-Levine, A., \& Brandenburg, M. (2010). Impact investments: An emerging asset class. (No. 6). New York: J.P. Morgan Global Research.

Organization for Economic Cooperation and Development (OECD). (2013). Policy brief on social entrepreneurship. Luxembourg: Organization for Economic Cooperation and Development. 
Parida, V., Sjödin, D., \& Reim, W. (2019). Reviewing literature on digitalization, business model innovation, and sustainable industry: Past achievements and future promises. Sustainability, 11(2), 391. doi:https://doi.org/10.3390/su11020391

Ragin, C. C., \& Becker, H. S. (1992). What is a case?: Exploring the foundations of social inquiry. Cambridge: Cambridge University Press.

Richter, M. (2013). Business model innovation for sustainable energy: German utilities and renewable energy. Energy Policy, 62, 1226-1237. doi:https://doi.org/10.1016/j.enpol.2013.05.038

Rivero Moreno, L. D. (2018). Museums and digital era: Preserving art through databases. Collection and Curation, 38(4), 89-93. doi:https://doi.org/10.1108/CC-02$\underline{2018-0002}$

Sanchez, P., \& Ricart, J. E. (2010). Business model innovation and sources of value creation in low- income markets. European Management Review, 7(3), 138-154. doi:https://doi.org/10.1057/emr.2010.16

Smithsonian Institution. (2001). Art museums and the public. Washington, D.C.: International Art Museums Division.

Spieth, P., Schneckenberg, D., \& Ricart, J. E. (2014). Business model innovation-state of the art and future challenges for the field. $R \& D$ Management, 44(3), 237-247. doi:https://doi.org/10.1111/radm.12071

Stack, J. (2013). Tate digital strategy 2013-15: Digital as a dimension of everything. Retrieved from https://www.tate.org.uk/research/publications/tate-papers/19/tate-digitalstrategy-2013-15-digital-as-a-dimension-of-everything

Stake, R. E. (1995). The art of case study research. London: Sage.

Stake, R. E. (2005). Multiple case study analysis. London: Guilford Press.

Stromberg, J. (2013). What digitization will do for the future of museums. Retrieved from https://www.smithsonianmag.com/smithsonian-institution/what-digitization-willdo-for-the-future-of-museums-2454655/

Svahn, F., Mathiassen, L., \& Lindgren, R. (2017). Embracing digital innovation in incumbent firms: How Volvo Cars managed competing concerns. MIS Quarterly, 41(1), 239-253. doi:https://doi.org/10.25300/MISQ/2017/41.1.12 
Tate. (2013). Tate report 2012/13. London: Tate.

Tate. (2014). Tate report 2013/14. London: Tate.

Tate. (2015). Tate report 2014/15. London: Tate.

Tate. (2016). Tate report 2015/16. London: Tate.

Tate. (2017). Tate report 2016/17. London: Tate.

Trendall, S. (2017). Q\&A with Tate digital director Ros Lawler - 'we want to make art accessible to everyone'. Retrieved from https://publictechnology.net/articles/features/qatate-digital-director-ros-lawler-\%E2\%80\%93-\%E2\%80\%98we-want-make-artaccessible-everyone $\%$ E2\%80\%99

Wang, Y. (2014). The role of large enterprises in museum digitization. Conservation Science in Cultural Heritage, 14(2), 67-72. doi:https://doi.org/10.6092/issn.1973-9494/5443

Weerawardena, J., McDonald, R. E., \& Mort, G. S. (2010). Sustainability of nonprofit organizations: An empirical investigation. Journal of World Business, 45(4), 346-356. doi:https://doi.org/10.1016/j.jwb.2009.08.004

Wirtz, J., Patterson, P. G., Kunz, W. H., Gruber, T., Lu, V. N., Paluch, S., \& Martins, A. (2018). Brave new world: Service robots in the frontline. Journal of Service Management, 29(5), 907-931.

Yin, R. K. (2017). Case study research and applications: Design and methods (6th ed.). Thousand Oaks, California: SAGE Publications.

Zott, C., \& Amit, R. (2007). Business model design and the performance of entrepreneurial firms. Organization Science, 18(2), 181-199. doi:https://doi.org/10.1287/orsc.1060.0232 
Table 1 Case Profiles

\begin{tabular}{|c|c|c|c|c|c|c|}
\hline Case & Location & $\begin{array}{l}\text { Sector and } \\
\text { Type }\end{array}$ & $\begin{array}{c}\text { Visitors } \\
\text { Annually }\end{array}$ & $\begin{array}{c}\text { Digitisation } \\
\text { Purpose }\end{array}$ & $\begin{array}{c}\text { Digital } \\
\text { Projects }\end{array}$ & $\begin{array}{c}\text { Digital } \\
\text { Category }\end{array}$ \\
\hline $\begin{array}{l}\text { Tate } \\
\text { Modern }\end{array}$ & $\begin{array}{l}\text { London, } \\
\text { UK }\end{array}$ & $\begin{array}{l}\text { Contemporary } \\
\text { Art Museum }\end{array}$ & $\begin{array}{l}6.4 \\
\text { million }\end{array}$ & $\begin{array}{l}\text { Building } \\
\text { relationships, } \\
\text { audience } \\
\text { engagement, } \\
\text { and self- } \\
\text { generated } \\
\text { income }\end{array}$ & $\begin{array}{l}\text { Tate Time } \\
\text { Machine: } \\
\text { digital } \\
\text { experience } \\
\text { that allows } \\
\text { visitors to } \\
\text { travel back in } \\
\text { time to } \\
\text { discover how } \\
\text { art has been } \\
\text { shaped by } \\
\text { history } \\
\\
\text { After Dark } \\
\text { Project: } \\
\text { roaming the } \\
\text { gallery at } \\
\text { night from } \\
\text { home using } \\
\text { guided robots }\end{array}$ & $\begin{array}{l}\text { Interactive } \\
\text { Services } \\
\text { Service } \\
\text { Robots } \\
\text { Artificial } \\
\text { Intelligence }\end{array}$ \\
\hline $\begin{array}{l}\text { Pompidou } \\
\text { Centre }\end{array}$ & $\begin{array}{l}\text { Paris, } \\
\text { France }\end{array}$ & $\begin{array}{l}\text { Contemporary } \\
\text { Art Museum }\end{array}$ & $\begin{array}{l}3.75 \\
\text { million }\end{array}$ & $\begin{array}{l}\text { Audience } \\
\text { engagement, } \\
\text { and self- } \\
\text { generated } \\
\text { income }\end{array}$ & $\begin{array}{l}\text { The Virtual } \\
\text { Centre: an } \\
\text { internet-based } \\
\text { cultural } \\
\text { content } \\
\text { broadcasting } \\
\text { platform }\end{array}$ & $\begin{array}{l}\text { Interactive } \\
\text { Services }\end{array}$ \\
\hline
\end{tabular}


Table 2 Thematic Categories and Sources of Data

\begin{tabular}{|c|c|c|}
\hline Categories & Data Sources & Type of Text \\
\hline $\begin{array}{l}\text { Digital Technologies } \\
\text { How do interactive services, } \\
\text { services robots, and artificial } \\
\text { intelligence increase customer } \\
\text { value and create new value? }\end{array}$ & $\begin{array}{l}\text { Tate Modern }(2013,2014, \\
\text { 2015, 2016, 2017) } \\
\text { Pompidou Centre }(2008,2017) \\
\text { Tate Modern }(2013,2014, \\
\text { 2015, 2016, 2017) } \\
\text { Pompidou Centre Strategic } \\
\text { Direction (2008) } \\
\text { The Guardian (2013, 2014) } \\
\text { Le Quotidien (2015) } \\
\text { La Tribune (2009) } \\
\text { CGI (2014) } \\
\text { Tafter Journal (2013) } \\
\text { Design Week (2016) } \\
\text { Tate Digital Strategy (2013) } \\
\text { Art Media Agency (2018) } \\
\text { Public Technology (2017) } \\
\text { Svegliamuseo (2014) } \\
\text { Framestore (2018) }\end{array}$ & $\begin{array}{l}\text { Annual report } \\
\text { Annual report } \\
\text { Minutes of Meetings } \\
\text { Document } \\
\text { Newspaper article } \\
\text { Newspaper article } \\
\text { Newspaper article } \\
\text { Research Report } \\
\text { Magazine article } \\
\text { Magazine article } \\
\text { Website } \\
\text { Website } \\
\text { Website } \\
\text { Website } \\
\text { Website }\end{array}$ \\
\hline
\end{tabular}


Table 3 Digital Projects and Outcomes for Tate Modern

\begin{tabular}{|c|c|c|}
\hline Digital Projects & Implications & BMI Outcomes \\
\hline $\begin{array}{l}\text { Tate Time Machine: digital } \\
\text { experience that allows visitors } \\
\text { to travel back in time to } \\
\text { discover how art has been } \\
\text { shaped by history }\end{array}$ & $\begin{array}{l}\text { Building relationships: } \\
\text { collecting audience data to } \\
\text { contact them after one year and } \\
\text { maintain a relationship }\end{array}$ & $\begin{array}{l}\text { Increasing customer value: } \\
\text { frequent visits to the gallery }\end{array}$ \\
\hline $\begin{array}{l}\text { IK Prize: a contest to present } \\
\text { ideas for using technology to } \\
\text { explore and enjoy art }\end{array}$ & $\begin{array}{l}\text { Building relationships: } \\
\text { compelling audiences to } \\
\text { participate in an art related } \\
\text { activity } \\
\text { Audience engagement: } \\
\text { sourcing ideas to develop } \\
\text { social mission }\end{array}$ & $\begin{array}{l}\text { Increasing customer value: } \\
\text { frequent visits to the gallery } \\
\text { Creating new value: co- } \\
\text { creation with audience of new } \\
\text { services }\end{array}$ \\
\hline $\begin{array}{l}\text { After Dark: roaming the gallery } \\
\text { at night from home using } \\
\text { guided robots }\end{array}$ & $\begin{array}{l}\text { Creating new aesthetic } \\
\text { experience: roaming the gallery } \\
\text { online through robots rather } \\
\text { than traditional visits }\end{array}$ & $\begin{array}{l}\text { Increasing customer value: } \\
\text { frequent visits to the gallery }\end{array}$ \\
\hline $\begin{array}{l}\text { Virtual Reality: interacting } \\
\text { with art virtually through an } \\
\text { immersive experience }\end{array}$ & $\begin{array}{l}\text { Creating new aesthetic } \\
\text { experience: interacting with art } \\
\text { that is in the studios of foreign } \\
\text { artists }\end{array}$ & $\begin{array}{l}\text { Increasing customer value: } \\
\text { higher engagement with the } \\
\text { gallery }\end{array}$ \\
\hline $\begin{array}{l}\text { Social Media: interacting with } \\
\text { audiences and promoting the } \\
\text { gallery }\end{array}$ & $\begin{array}{l}\text { Audience engagement: keeping } \\
\text { audiences informed of news } \\
\text { and engaging online }\end{array}$ & $\begin{array}{l}\text { Increasing customer value: } \\
\text { higher engagement with the } \\
\text { gallery }\end{array}$ \\
\hline $\begin{array}{l}\text { Online Membership: a paid } \\
\text { scheme to enjoy exclusive } \\
\text { benefits }\end{array}$ & $\begin{array}{l}\text { Building relationships: } \\
\text { maintaining a long-term } \\
\text { relationship with audiences to } \\
\text { inform them about exhibitions } \\
\text { to attend and give special } \\
\text { offers } \\
\text { Diversifying self-generated } \\
\text { income: a paid annual } \\
\text { membership that generates } \\
\text { revenue from members }\end{array}$ & $\begin{array}{l}\text { Increasing customer value: } \\
\text { frequent visits to the gallery } \\
\text { and recurring income per } \\
\text { customer } \\
\text { Creating new value: new } \\
\text { revenue streams }\end{array}$ \\
\hline $\begin{array}{l}\text { Online Shop: selling digital and } \\
\text { physical products including } \\
\text { online courses, e-books, gifts, } \\
\text { among others }\end{array}$ & $\begin{array}{l}\text { Diversifying self-generated } \\
\text { income: increased revenue } \\
\text { from sales of products }\end{array}$ & $\begin{array}{l}\text { Creating new value: wider } \\
\text { access to the shop and sales to } \\
\text { customers globally }\end{array}$ \\
\hline
\end{tabular}


Figure 1 The Implications of the Virtual Experience on the Performance of the Pompidou Centre

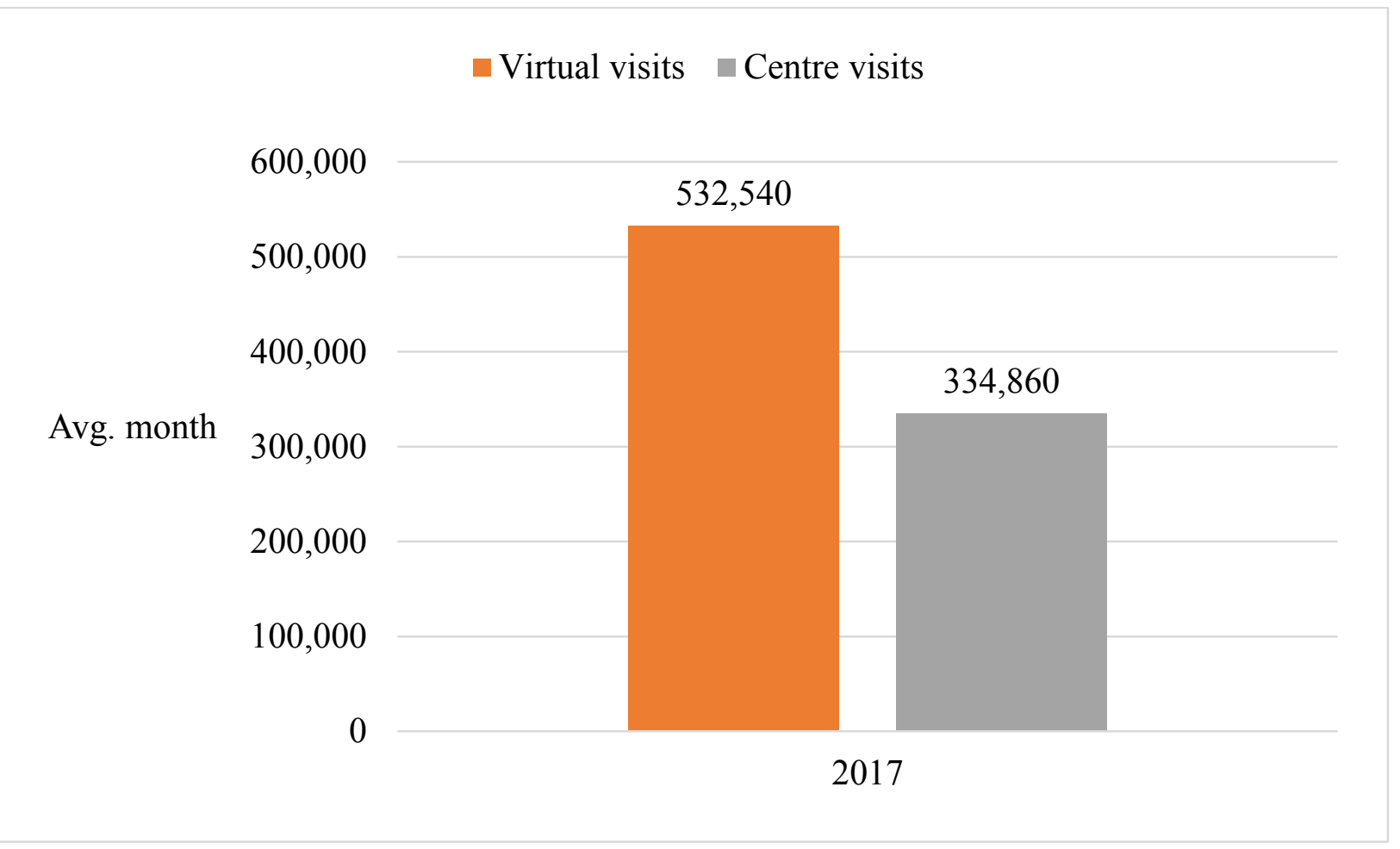

Source: Pompidou Centre Annual Report (2017) 
Figure 2 Online Membership Income to Other Trading Income in Tate Modern

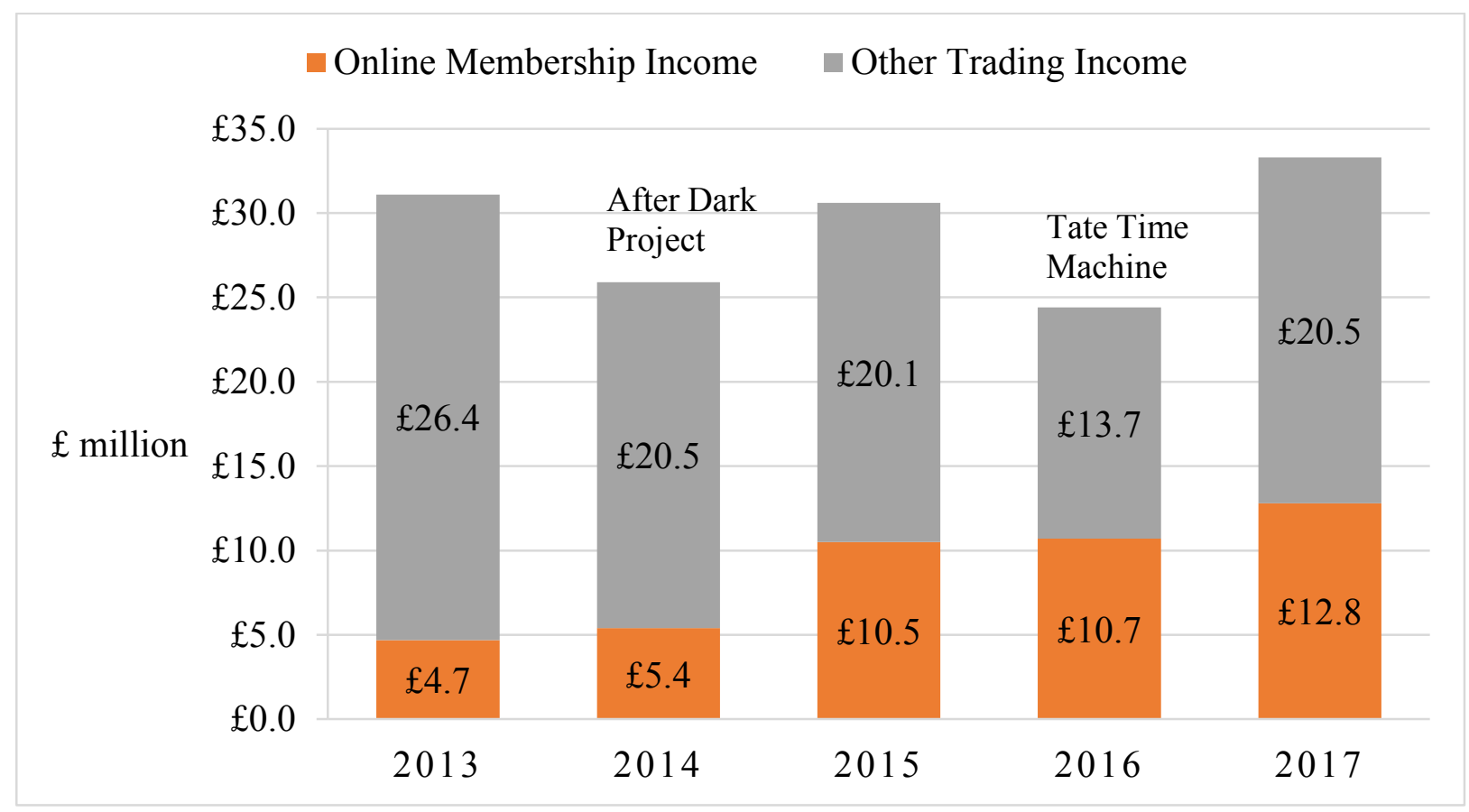

Source: Tate Annual Report (2013, 2014, 2015, 2016, 2017) 
Figure 3 Digitisation and Business Model Innovation in Social Purpose Organisations

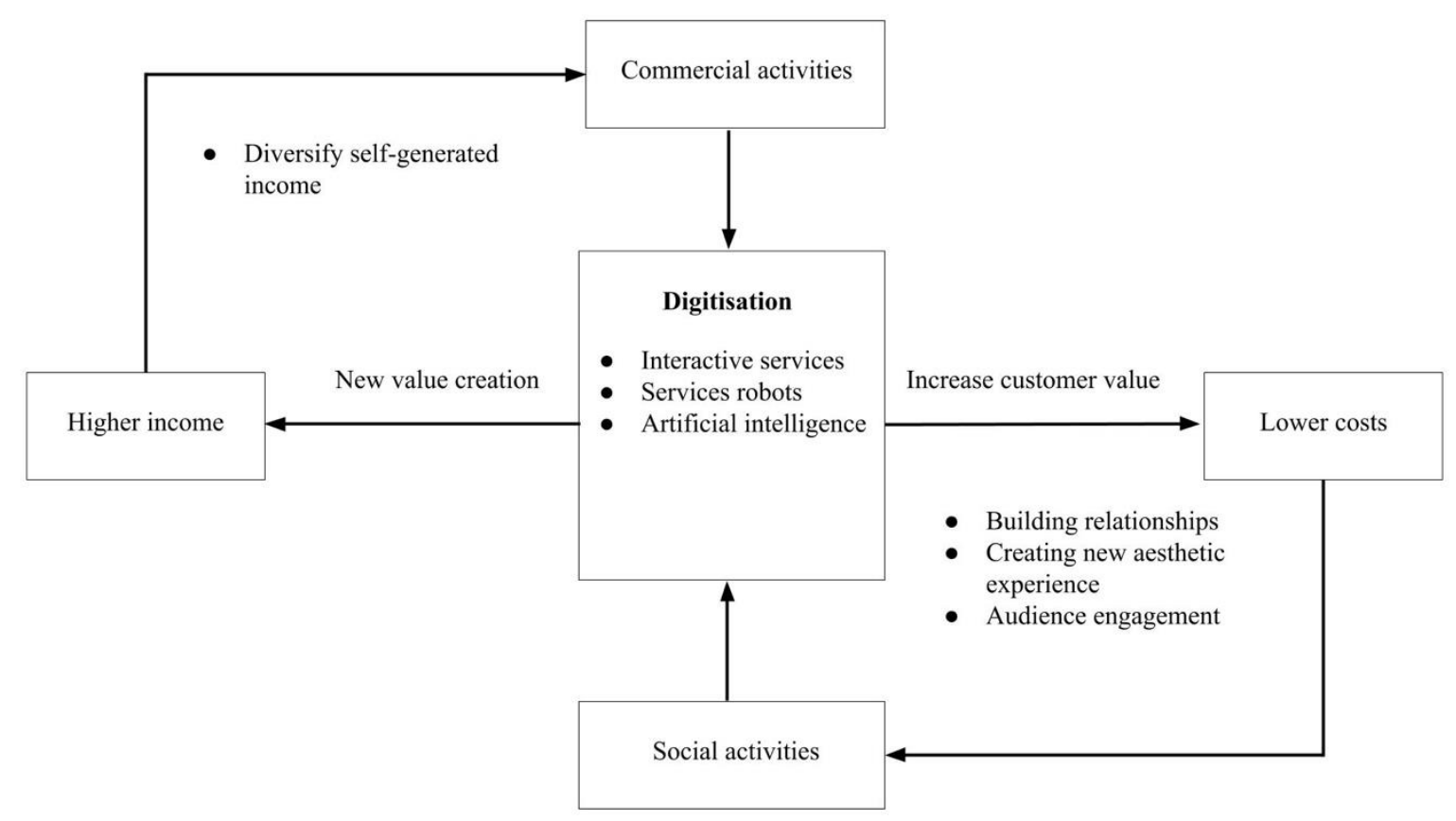




\section{Research Highlights}

- This study examines the effect of digitisation on business model innovation of social purpose organisations based on a comparative case analysis of Tate Modern and Pompidou Centre.

- Digitisation is revitalising social purpose organisations by innovating their business models.

- Digitisation enables creative revenue streams that directly affect the social mission by creating a synergy between trade and social activities.

- Digitalisation delivers social value to a larger audiences with lower costs by engaging with visitors through virtual experiences.

- Digitisation provides a mechanism for business model innovation in social purpose organisations for enhanced financial autonomy and greater social value. 


\section{Author Biographies}

Nasser Alshawaaf is a PhD researcher at Kent Business School, University of Kent, UK. His research focuses on the role of micro-level mechanisms in the emergence of institutional logics in the context of art museums in the UK and France. He has presented papers at the British Academy of Management and the Social Theory, Politics \& the Arts Conference.

Soo Hee Lee is Professor in Organization Studies at Kent Business School, University of Kent, UK. He is the Director of the Creative City Forum in Korea and a vice-president of the Korean Association for Cultural Economics. His research focuses on institutional and behavioural underpinnings of creativity and organisational dynamics and discourses of knowledge, trust and power. More recently, his research has explored digital convergence and collective creativity in the fields of architecture, fashion, food, contemporary visual art and dance. 